\title{
THE ROLE OF DIASPORE BANKS \\ FOR THE RESTORATION OF FLOODPLAIN MEADOWS. RESULTS OF A LONG TERM MONITORING ON THE NORTHERN UPPER RHINE (GERMANY)
}

Erika SCHNEIDER-BINDER *

\begin{abstract}
* Karlsruhe Institute for Technology - University of Land Baden-Württemberg and Research Center of the Helmholtz Society, Institute for Geography and Geoecology, Department WWF-Institute for Floodplain Ecology, Josefstrasse 1, Rastatt, Germany, D-76437, erika.schneider@kit.partner.edu, erika.schb@t-online.de
\end{abstract}

DOI: 10.1515/trser-2017-0010

KEYWORDS: diaspores in the soil, seed dispersal, seed longevity, succession stages of floodplain meadows.

\section{ABSTRACT}

The reconnection of the inner area of the island Kühkopf/Northern Upper Rhine to the hydrological dynamic of the river was the beginning of a large scale restoration programme for turning back to the previous vegetation - floodplain meadows. From the various aspects of the restoration are presented the succession phases; species with their different type of dispersal are analysed as well. A special attention is given to the role of diaspores of the soil, which play an important role in the redevelopment of floodplain meadows. Species of the diaspore bank can recur after many years, if favourable conditions are available. These are related to floods, dryness and rooting up by wild boar with the development of micro-succession stages.

ZUSAMMENFASSUNG: Die Rolle der Diasporenbank für die Renaturierung von Auenwiesen. Ergebnisse eines Langzeitmonitorings am nördlichen Oberrhein (Deutchland).

Die Wiederanbindung der inneren Bereiche des Kühkopfs an die Dynamik des Rheins war der Beginn eines umfassenden Programmes zur Wiederherstellung von Auenwiesen. Aus der Fülle der untersuchten Aspekte werden die unterschiedlichen Entwicklungsphasen vorgestellt und die Arten nach ihrem Verbreitungsmodus analysiert. Besondere Aufmerksamkeit gilt dem Diasporenreservoir des Bodens, das unter bestimmten Bedingungen nach Hochwasserereignissen, sommerlicher Trockenheit oder Brechen der Grasnarbe durch Wildschweine aktiviert wird. Dabei entstehen charakteristische Mikrosukzessionen.

REZUMAT: Rolul băncii de diaspori în redezvoltarea fâneţelor aluviale. Un monitoring de lungă durată în lunca sectorului nordic al Rinului superior (Germania).

Reconectarea părţii interioare a insulei Kühkopf la dinamica hidrologică a Rinului a constituit începutul unui larg program de reconstrucţie ecologică a fânețelor de luncă, existente în zonă înaintea practicării unei agriculturi intensive. Dintre variatele aspecte ale refacerii pajiştilor de luncă sunt prezentate diferitele stadii de dezvoltare, fiind apoi analizate speciile cu modalitățile lor de dispersie. O atenţie specială este dată rolului diasporilor din sol. Speciile pot să apară după timp îndelungat, în caz că se ivesc condiții favorabile de germinare. Acestea sunt legate de viituri, secetă estivală şi de activitatea de râmat a porcilor mistreţi, creându-se micro-succesiuni caracteristice. 


\section{INTRODUCTION}

For the restoration of previously existing vegetation after change of land use, i.e. the transformation of agricultural lands into extensively used riverine floodplain meadows, dispersal units of plants are of great importance, they constitute a functional unit influencing the dynamics of populations and plant communities and should be considered in conservation and restoration programmes (Bornkamm et al., 1991; Poschlod, 1991; Curtean-Bănăduc et al., 2014). In particular the diaspore bank of the soil - seeds and fragments of rhizomes - plays an important role for restoration of floodplain meadows (Poschlod, 1991; Dister et al., 1992).

The opportunity for floodplain restoration through natural succession (without the influence of man) and controlled by mowing arose on the Northern Upper Rhine in the floodplain area of Kühkopf, part of the Nature Reserve and Natura 2000 site "KühkopfKnoblochsaue” (Fig. 1).

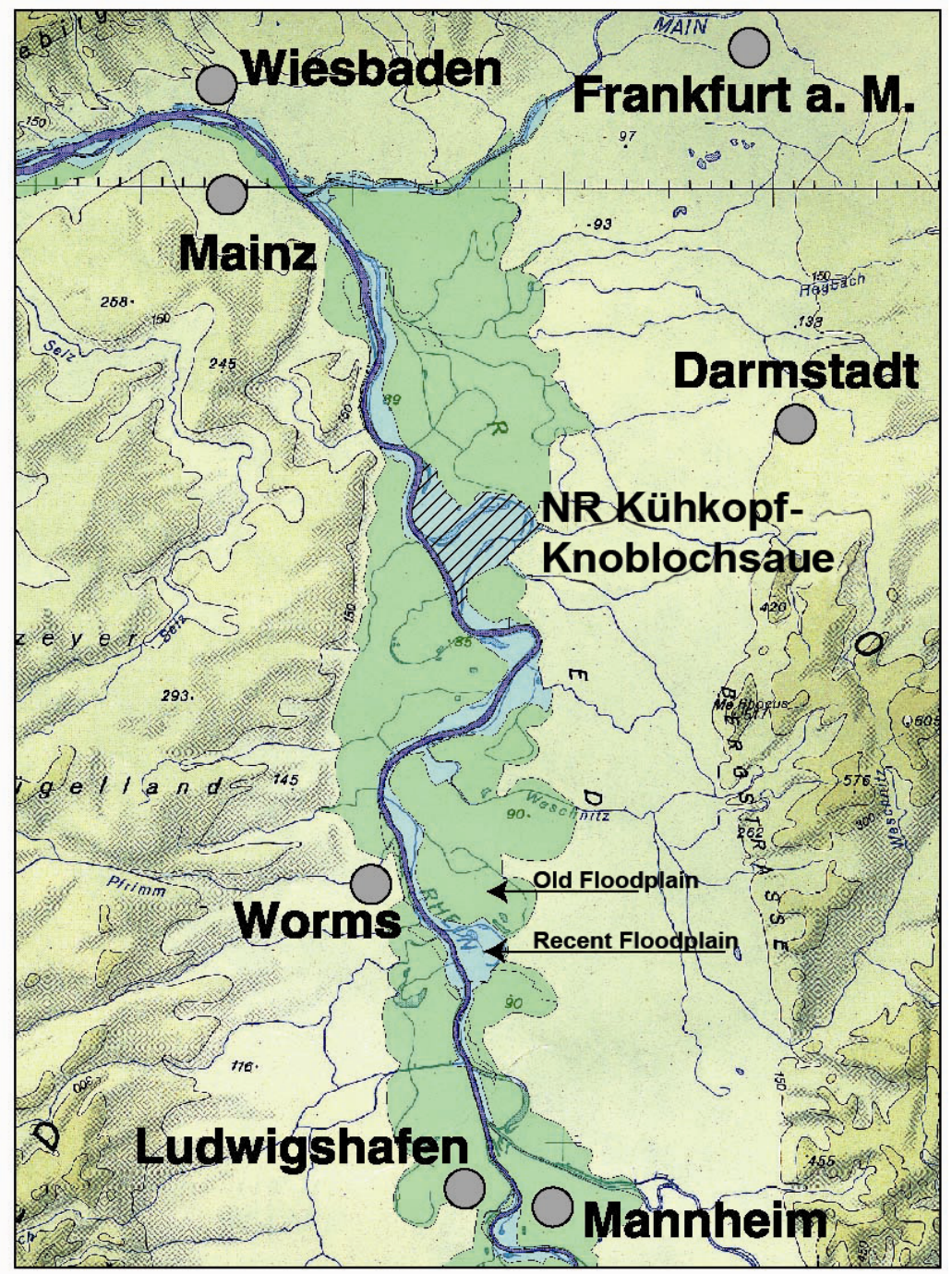

Figure 1: Geographical position of the Kühkopf on the Northern Upper Rhine (source: Auen-Institut, Rastatt). 
The Kühkopf is an island that emerged from the cutting of a great meander of the river Rhine in 1828/1829. From that time the island has been surrounded by the Stockstadt-Erfelder Old Rhine and in its Western part by the New Rhine. The inner part of the island has been protected against floods by a system of dykes. In the three independent polders (A, B, C) with a total of 700 ha, on 400 ha agriculture - more recently intensively - has been practiced; 300 ha are covered by hardwood floodplain forest. The site's intensive use for crop breeding had constituted a permanent conflict between agriculture and nature protection. Then, after a dyke break as a consequence of high floods in spring 1983 with two peaks, the one in April and the next at the end of May, the agricultural use of the crop breeding station came to an end. The reconnection of the inner part of the area to the natural hydrological regime of the river Rhine and the decision to take the land out the agricultural use was the beginning of a large scale restoration programme with possibilities for a long-term monitoring on experimental plots scientifically followed from 1986-2001, 2005-2008 and 2014 and will be continued in subsequent years. (Dister et al., 1986, 1992; Schneider, 1995, 2001; Schneider et al., 1994)

The restoration raises many questions related to the phases of succession and the influencing factors which in floodplains are more complex than in the area outside the floodplains. They are strongly related to the flooding, the changes between high and low water levels, mainly the seasonal occurrence of floods, their height, duration and frequency, dry periods of the years and as well to the existing dispersal units of plants, the means of distribution and the competition capacity of the species and their populations. From the comprehensive volume of data monitored over more than two decades, this paper will present only some aspects related to the phases of the controlled succession by mowing and the role of the different dispersion of species with regard to the role of the diaspore bank of the soils.

The area subjected to natural and controlled succession in the past to a minor degree has been analysed from the point of view of dispersal biology (Schmidt, 1981). Only from the last two decades of the 20th century this type of analysis entered more and more into the attention of succession researches. The dispersal analysis can suggest the way of colonisation of species from the surrounding flora contributing to the restoration of the previous vegetation. Beside species of the diaspores bank of the soil, which can germinate in favourable conditions, in the first colonisation phase anemochorous dispersal, by wind-dispersed species, play an important role, species of other types of dispersal being on the beginning of succession of minor importance (see also Schmidt, 1981). Later the zoochorous dispersal plays as well an important role.

\section{MATERIAL AND METHODS}

In order to improve scientific knowledge in the field of succession of vegetation for restoration of floodplain meadows, permanent plots for natural succession (without the influence of man) for the development of floodplain forests and controlled succession with regularly mowing for restoration of floodplain meadows have been established on sites with various soil conditions (different content of sand and different micro-relief and height).

So as to document also the influence of game (wild boar, deer) on the course of succession, fenced and non-fenced plots have been established for each experimental area. A varied network of experimental variants has thus been established (Fig. 2). For the monitoring of controlled succession four areas were chosen; two in Polder A "Vor dem Eichwald"/A1 (altitude $86.7 \mathrm{~m}$ above $\mathrm{NN}$ ) and "Ochsenlache"/A2 (altitude $86.25 \mathrm{~m}$ a. NN), one in Polder B "Schafweide” (altitude $85.8 \mathrm{~m}$ a.NN) and one in Polder C "Plattenacker" (altitude $86.5 \mathrm{~m} \mathrm{NN}$ ) 
(Dister et al., 1987) (Fig. 2). The fenced and non-fenced plots of $10 \mathrm{x} 30 \mathrm{~m}$, were subdivided into smaller plot units, each including two 5 x 5 m quadrats (a1 and a2 non-fenced, b1 and b2 fenced), so that a total of sixteen identical permanent plots were included in the monitoring programme. As well a smaller area $(1 \mathrm{x} 1 \mathrm{~m})$ for detailed studies of species distribution has been established, all plots being surrounded by a buffer zone. For the study of microsuccessions the sampling area has been adapted to the extent of the area rooted up by wild boar. The quantitative and qualitative changes of the controlled succession for restoration of floodplain meadows on the abandoned agricultural lands were realized through comparative analysis of species composition, the distribution of the dominant species in the plot, the changes from one year to the other of the abundance and dominance of species and as well the change of structure and plant composition in the plot under the impact of different influencing factors such are high floods, soil rooting up by wild boar and summer dryness.

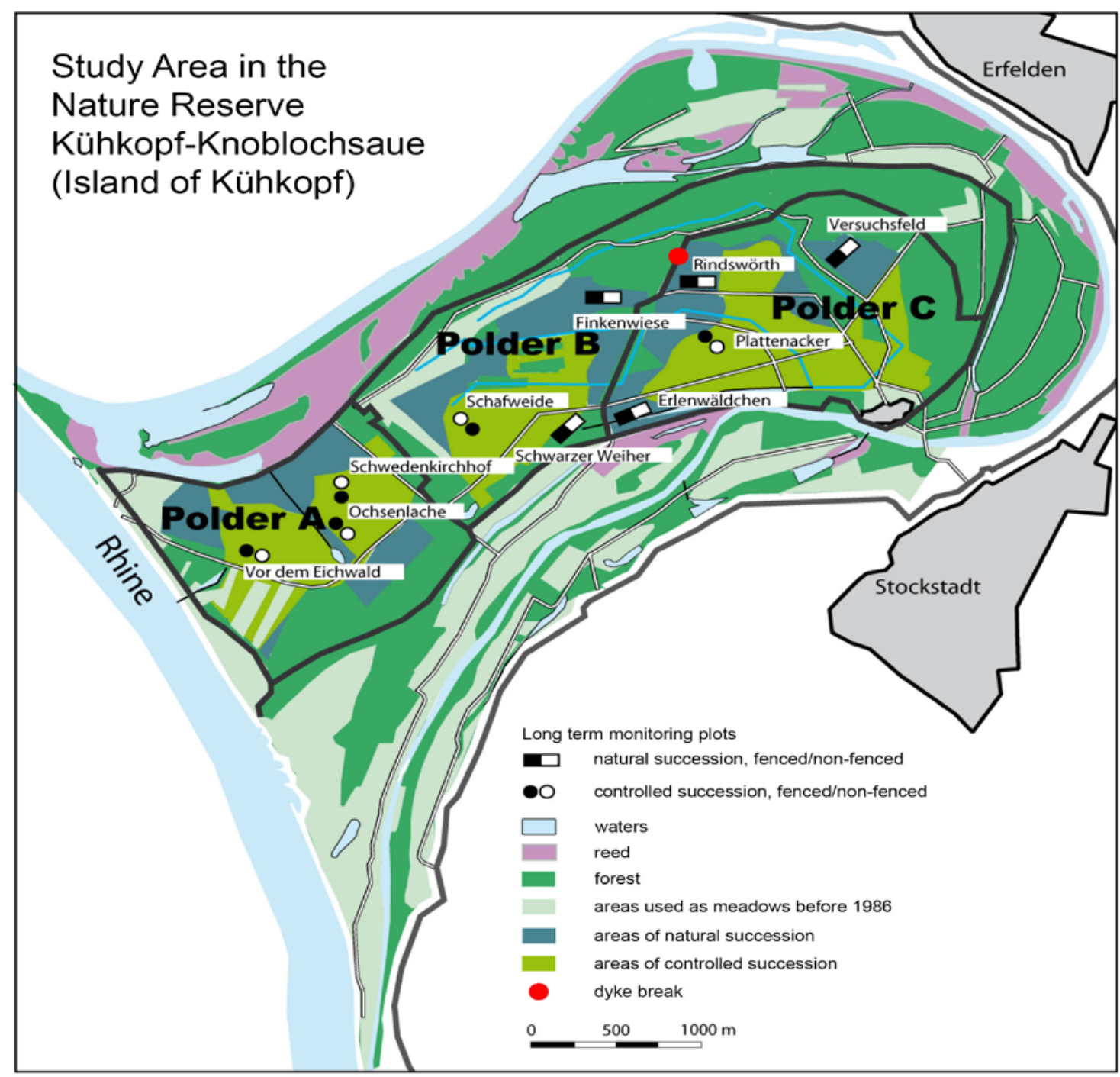

Figure 2: Study area on the Kühkopf, part of the Nature Reserve and Natura 2000 site Kühkopf-Knoblochsaue Northern Upper Rhine/Germany. 
The plots were analysed annually by phytocoenological methods, according to BraunBlanquet (1964), and as well other refined methods for the analysis of structure and sociability characteristics (Schmidt, 1981; Fischer, 1987; Dister et al., 1986, 1987; Schneider et al., 1994). The samples are included in phyto-coenological tables indicating for each species data about bioform, phytocoenological units, modality of dispersion and indicator value for wetness and nitrogen (Müller-Schneider, 1977) for dispersal units (Ellenberg et al., 2001).

The studied plots, fenced and non-fenced, were subjected to regular mowing, each year in the same time period from the beginning to the middle of June (depending on the flood events), harvested and removed from the area. Only in the first two years did mulching take place, the vegetation being open and the degree of cover very low. Depending on the weather in late August a second mowing took place.

\section{RESULTS AND DISCUSSION}

After the high floods of May 1983 and the definitive abandonment of agricultural use, colonization started in controlled plots (moving once or twice a year) and the succession went through various stages, from the stage of annual weeds of root crop (Chenopodietea) and cereal cultivation (Secalietea), i.e. Therophytes (in the first and the second year of succession 1983, 1984) to that of ruderal Hemicryptophytes (in the third, fourth and fifth year) and eventually the grass stage with herbs beginning in the fifth and sixth year (Dister et al., 1986 1987, 1991; Schneider, 2001, 2002).

Dominant species have been in the first stage, among others, Chenopodium album, Polygonum persicaria (Persicaria maculosa), Amaranthus retroflexus, Amaranthius hybridus, Matricaria discoidea, Sonchus asper Coronopus squamatus, Conyza canadensis and Capsella bursa-pastoris (Dister et al., 1992). Remarkable has been the occurrence on a large area of the solanaceous weeds Hyoscyamus niger and Datura stramonium (Polder A and C) and common poppy (Papaver rhoeas) (Polder B).

Due to the inner area of Kühkopf isolation by the surrounding Stockstadt-Erfelden old meander and a forest belt we have to assume that these species developed from the re-activated diaspore bank of the soil. The re-activation includes species from older agricultural land use and from former old floodplain meadows (Dister et al., 1992; Schneider, 1995; Fischer, 1987).

In the third year (1985) the above-mentioned weeds mostly disappeared or occurred in a smaller area, a characteristic being at this stage a competition of annual weeds - all Therophytes - with also short-lived, mostly biennial Hemicrypothytes, indicating an early stage of ruderal tall herbaceous vegetation. The following stage of ruderal hemicryptophytes and geophytes with rhizomes, was dominated by creeping thistle (Cirsum arvense) and locally by couch-grass (Elymus repens) in the third and fourth year (partly in 1985 and in 1986) (Fig. 3 ). From the beginning of the succession the couch-grass became dominant in certain area.

As a consequence of the 1987 long summer flood and the selection between flood resistant, flood tolerant and flood intolerant species the thistle has been eliminated more rapidly, and common dandelion (Taraxacum officinale) has extended on some areas but in others has retreated. At the same time, stoloniferous grasses such as creeping bent (Agrostis stolonifera) and rough meadow-grass (Poa trivialis) have spread. This was the beginning of the establishing of a grass stage with herbs, in particular species from the pea family (Fabaceae), which developed micro-facies structures showing "flowerbed" aspects (Fig. 4). This structure remained for four-five years and changed more or less rapidly due to fluctuating water tables. Finally, regular cutting altered these micro-facies structures and the area's aspect became similar to natural floodplain meadows dominated by different grass stages. 
In the eighth year and even more in the ninth year, the grasslands growing in the more elevated places turned into Arrhenatheretum elatioris-like meadows, but still a typical composition and many of the characteristic were lacking. Adjacent to the tall oat-grass (Arrhenatherum elatius) meadows, but in the lower-lying spots, the floodplain meadows were dominated by meadow foxtail (Alopecurus pratensis), this last having a higher wetness tolerance than tall oat grass (Ellenberg et al., 2001). In the lowest places, i.e. the more or less regularly flooded sites, one finds wet meadows with swamp meadow-grass (Poa palustris). In the further course of succession, in the twelfth year of meadows development (1994) tall oatgrass (Arrhenatherum elatius), meadow foxtail (Alopecrus pratensis) and swamp meadowgrass (Poa palustris) covered larger area according to their wetness requirements, the swamp meadow-grass being restricted to the lowest levels, the existing small depressions and flood channels. With the development and spreading of the tall oat grass and the meadow foxtail, characteristic accompanying species for these communities appeared, such as Galium mollugo, Centaurea jacea and Campanula patula. In the foxtail-meadows Inula salicina and Lychnis flos-cuculi occurred on some places (Schneider, 2002).

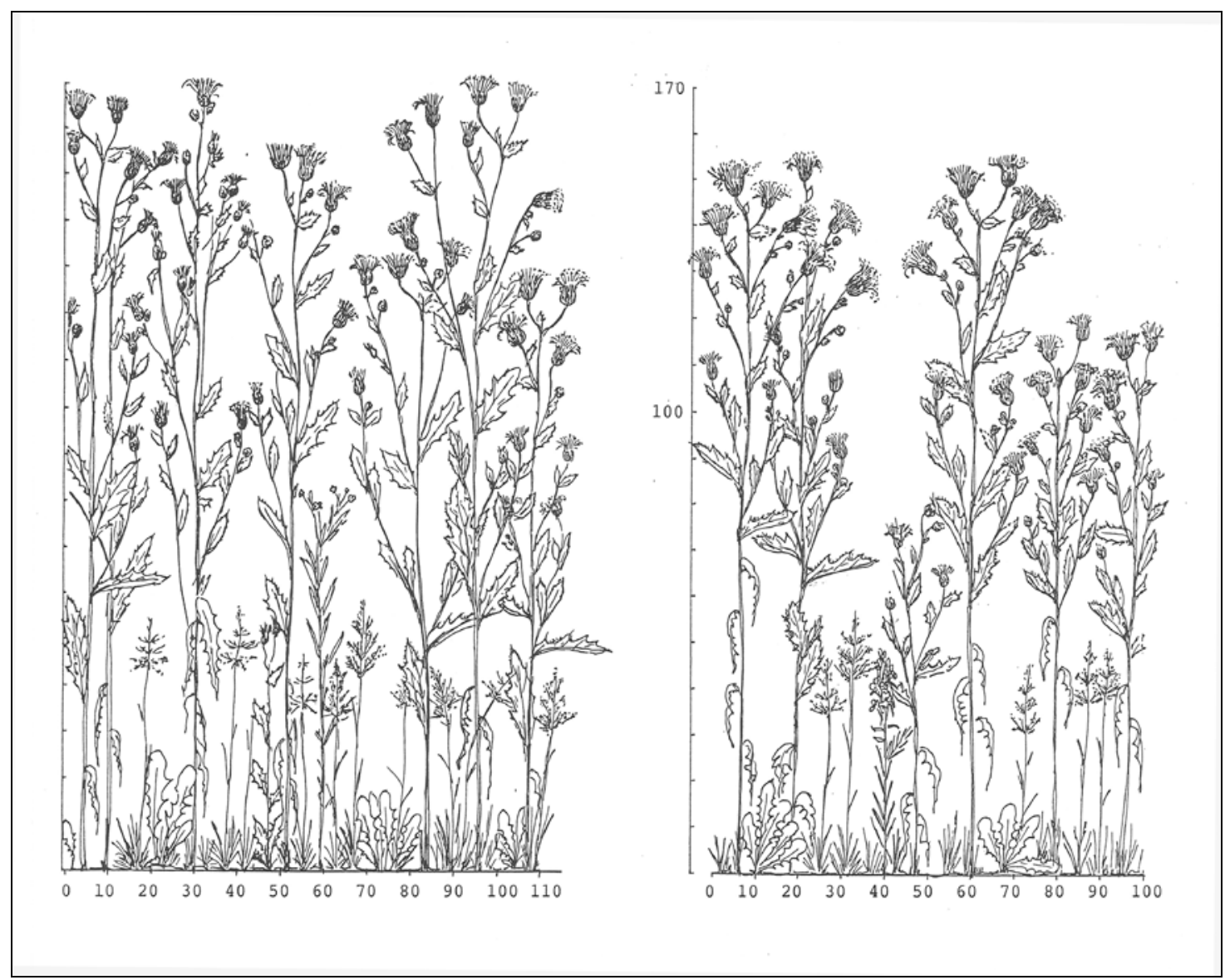

Figure 3: Stage of ruderal Hemicrypthophytes, dominated by Creeping thistle (Cisium arvense) with smaller wet-tolerant grasses on the low level. 


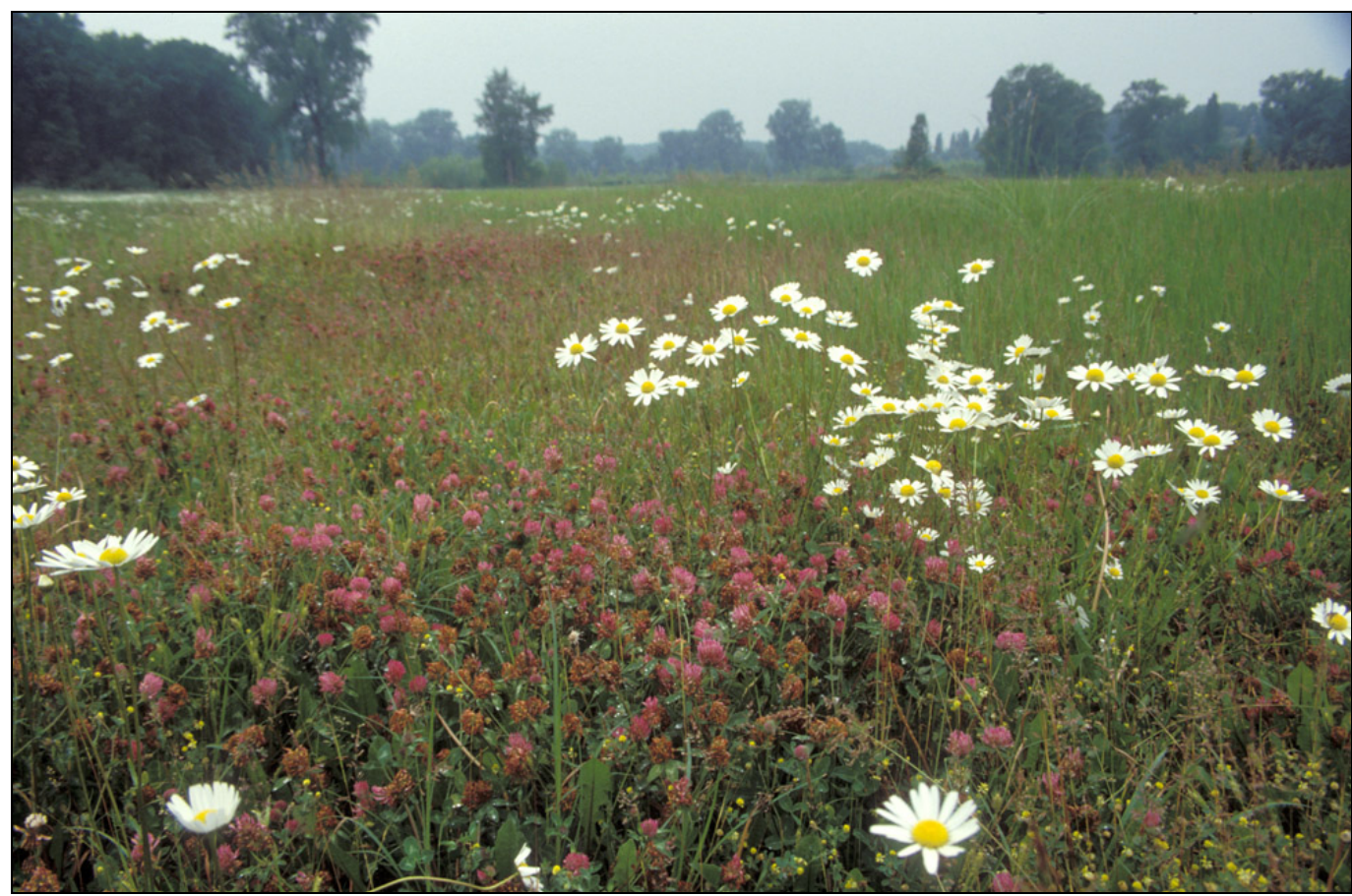

Figure 4: Micro-facies structures showing "flowerbed" aspects with red clover (Trifolium pratense) and ox-eye daisy (Chrysanthemum leucanthemum).

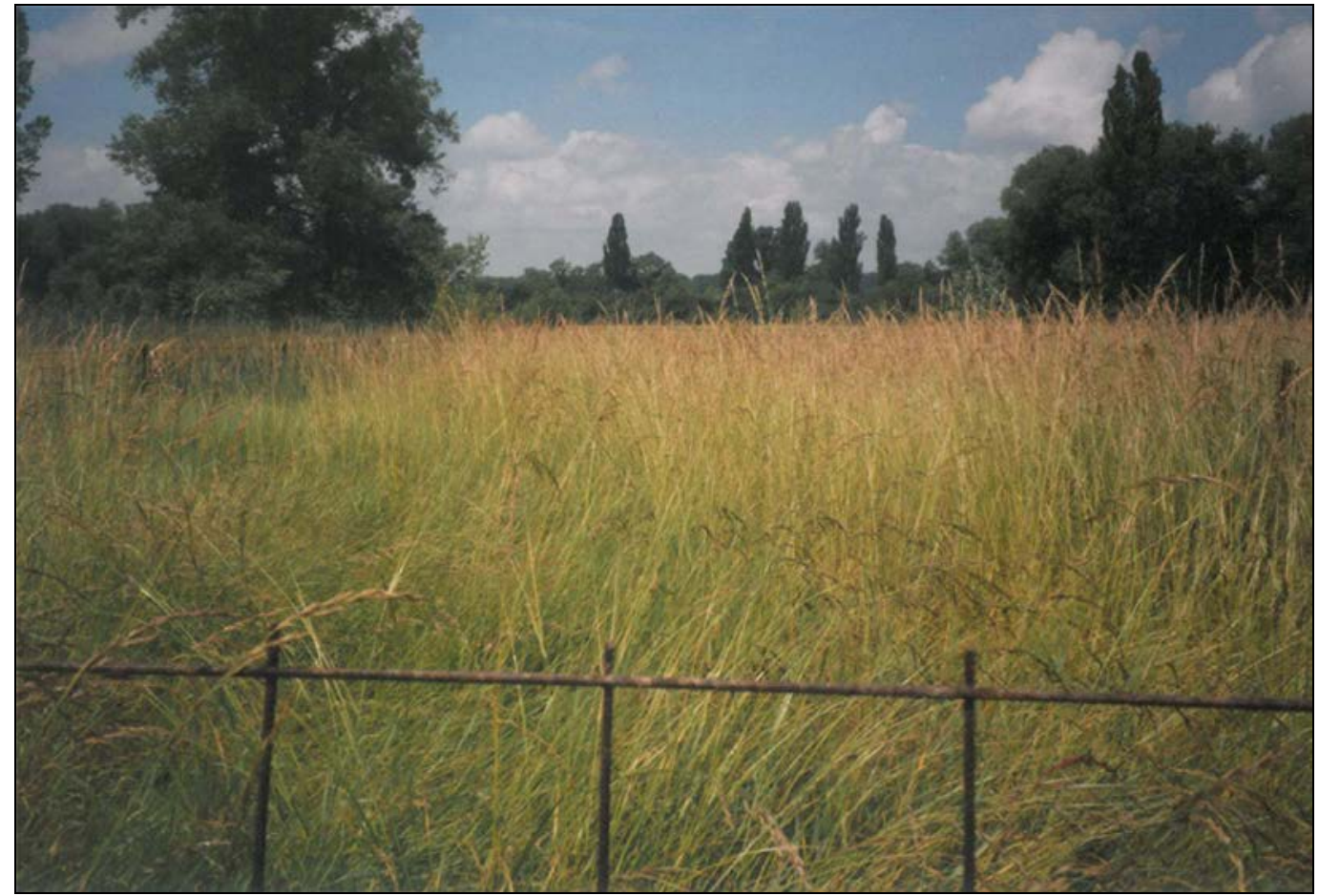

Figure 5: Grass stage in the sampling area with dominant tall fescue (Festuca arundinacea) and tall oat-grass (Arrhenatherum elatius). 
As a consequence of the dry summer of 1991 a large disturbance of the plots took place, many species susceptible to dryness such as Poa palustris, P. trivialis, Potentilla reptans and others disappeared (Dister et al., 1991) and occurred again two years later. After the summer flood of 1999 large changes in the abundance of different species toke place in the grasslands cover of the Kühkopf area. The degree of cover of Arrhenatherum elatius and Alopecurus pratensis decreased and tall fescue (Festuca arundinacea) spread and dominated over a large area, a situation during more years and existing as well today in large parts of the polders, including the monitored plots.

The development in relation to the hydrological regime, the changes between flooding and drying out, are the influencing factors as well for the re-activation of diaspores of the soil. They play an important role not only in the first colonization of the abandoned agricultural lands, but also in the course of succession, when disturbances such are, high floods, dryness and rooting up by wild boars arise. Dry summertimes combined with rooting up by wild boar are the basis for the re-activation and spreading of xero-thermophilous species from the diaspore reservoir of the soil.

Near the species from the diaspore bank of the soil, occurring if site conditions are good, anemochorous wind-dispersed species play a main role in the first colonization phase (Schmidt, 1981), and in the later succession course if changing ecological conditions. From the species with other dispersal mechanisms the zoochorous and anemo-zoochorous species play an important role (Figs. 6 and 7). The species number as a whole and the number of anemochorous, zoochorous and anemo-zoochorous species is variable from year to year in function of the flood events and dryness in the area. Remarkable changes over the years are exemplified by two sampling data of the year 1987, before and after a high flood with long duration with remarkable differences in species number as a whole and as well from the three categories of seed dispersion.

The activation of the diaspore bank includes different aspects. As in the studied case, diaspores with long-term persistence occurred - mostly weeds from former traditional agricultural land use and housing, as well diaspores of species from older floodplain meadows such as Viola elatior, Anacamptis pyramidalis and Ranunculus bulbosus, which existed before the agricultural land use and survived as diaspores in the soil. As it is stated during other researches diaspores are concentrated on the upper $30 \mathrm{~cm}$ of the floodplain soil (around $60-80 \%$ of the diaspores). Diaspores can rarely be found deeper than $50 \mathrm{~cm}$ (Hölzel and Otte, 2003). But a special case of persistence of diaspores in the seed bank of soils is given by the black henbane (Hyoscyamus niger) in the succession area of Kühkopf. The species colonized large area on the beginning of the succession in the first and second year (after dam breaking), disappearing again for a time. In 1992 it occurred again in places rooted up by wild boar. These rooted up area constitute the beginning of a new micro-succession in between the larger area of succession in a more advanced phase of evolution to meadows (Schneider, 2002). Later occurrence has been registered in 1998 and 2005 also in the wild boar rooting up area. The occurrence of the black henbane, a species with long-term persistence in the diaspore bank of the soil was reported also in other parts of the Upper Rhine, after large and deep earth moving for hydro-technical construction (Carbiener, oral communication). From these observations it can be stated that the seeds of black henbane can survive also in deeper soil levels and from older times. The longevity of the seeds of black henbane has been mentioned up to 650 years (Poschlod, 1991). 


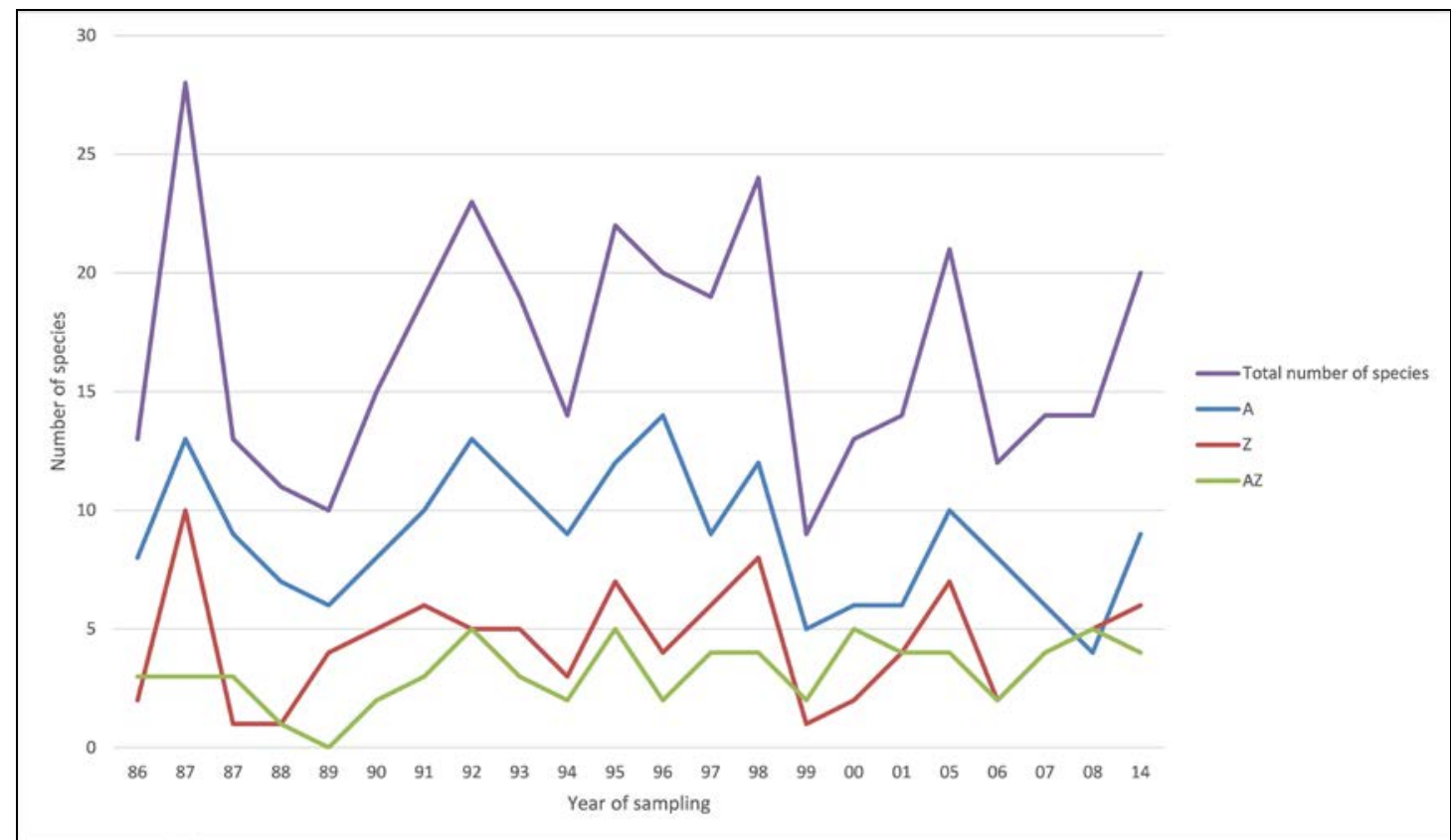

Figure 6: Number of anemochorous (A), zoochorous (Z) and anemo-zoochorous species in comparison with the total number of species in the sampling plots A2 "Ochsenlache" from 1986-2001, 2005-2008 and 2014; the year 1987 is represented with two samples before and after a high flood of long duration.

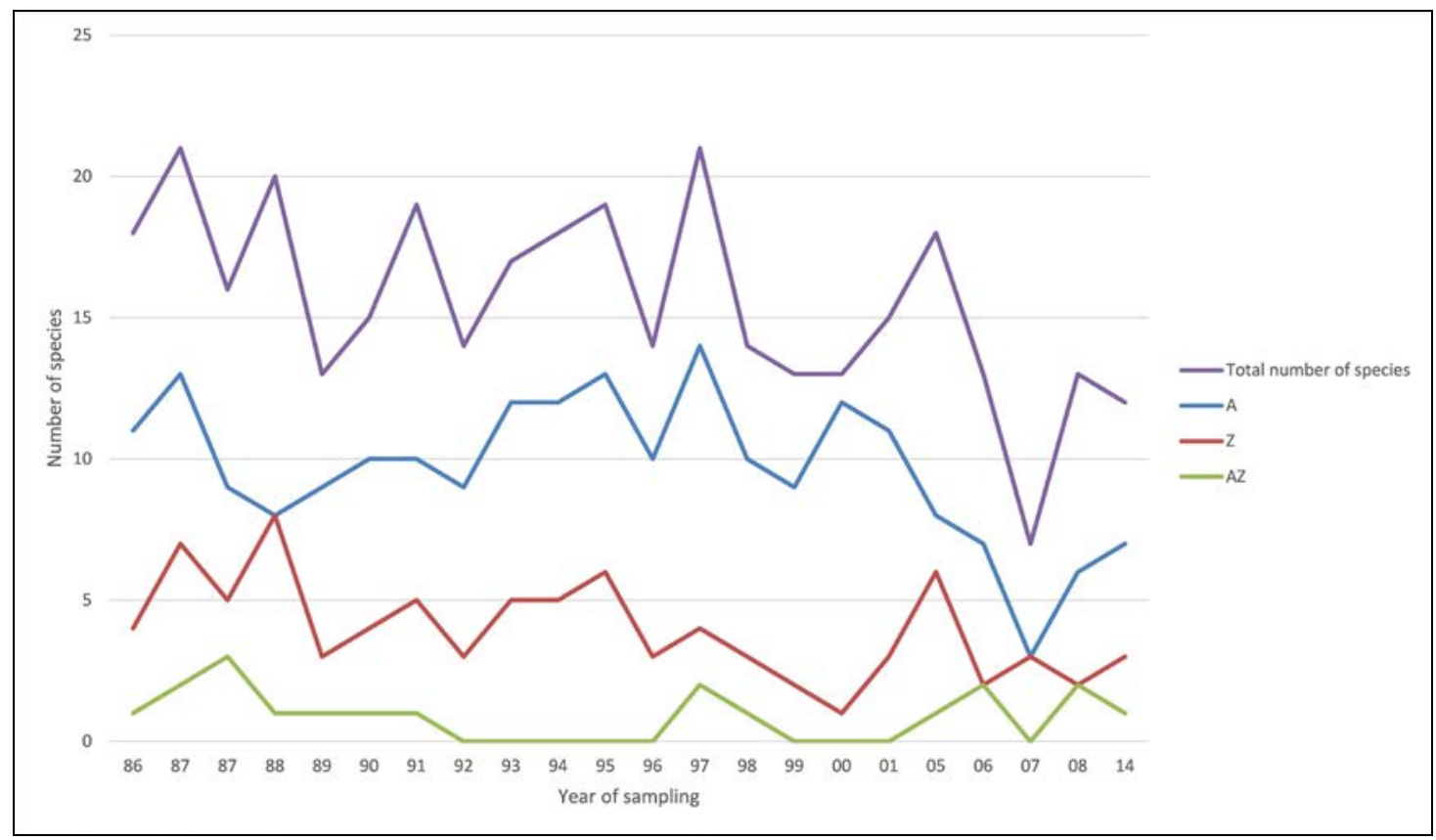

Figure 7: Number of anemochorous (A), zoochorous (Z) and anemo-zoochorous (AZ) species in comparison with the total number of species in the sampling plots of the area $\mathrm{C}$

“Plattenacker” from 1986-2001, 2005-2008 and 2014. 


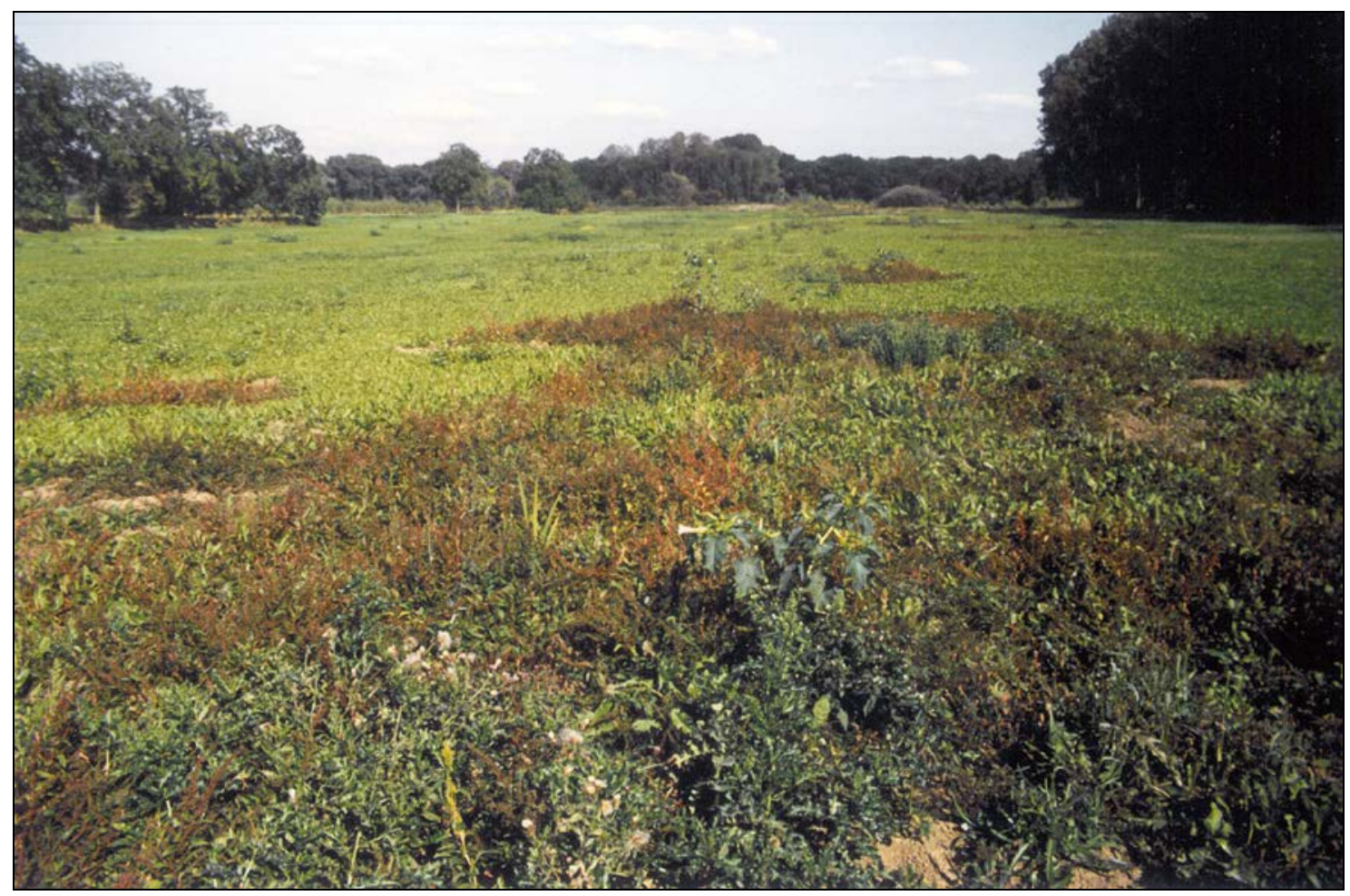

Figure 8: Micro-succession in a meadow-like succession stage

with species occurred from the reactivation of the seed bank of the soil (1992).

On wild boar rooting up sites there occurred in 1993 a typical community of weeds of old agricultural lands, Mercurialetum annuae Krusem. and Vlieg. 39 em. Th. Müller, composed of the thermophilous, sub-Mediterranean, sub-Atlantic species Mercurialis annua and including a large number of other thermophilous species such as Datura stramonium, Hyoscyamus niger, Euphorbia helioscopia, Lathyrus tuberosus, and others (Tab. 1).

This plant community, indicating old land use by root crop cultures (Oberdorfer, 1993), has to be considered also as a reactivation of the diaspore bank of the soil. This community became very rare on the Upper Rhine and in the last decades up to the 1970s has not been observed, being considered as having disappeared.

During the studies and long term monitoring the community has been observed in 1993 (Schneider and Dister, 1993; Schneider, 1995) and also later in 1998 and 2005 (unpublished data). 
Table 1: Mercurialetum annuae Krusem. and Vlieg. $39 \mathrm{em}$. Th. Müller facies with Datura stramonium and Hyoscyamus niger.

\begin{tabular}{|c|c|c|c|c|c|c|c|c|c|c|c|c|c|}
\hline \multicolumn{3}{|c|}{ Number of sample } & 1 & 2 & 3 & 4 & 5 & 6 & 7 & 8 & 9 & 10 & \\
\hline \multicolumn{3}{|c|}{ Size of sample } & 25 & 20 & 25 & 35 & 12 & 20 & 113 & 30 & 30 & 12 & \\
\hline \multicolumn{3}{|c|}{ Coverage degree (\%) } & 65 & 50 & 30 & 40 & 45 & 75 & 60 & 60 & 30 & 55 & \\
\hline Biof. & PhSoc & & & & & & & & & & & & C \\
\hline $\mathrm{T}$ & $\mathrm{FE}$ & $\begin{array}{l}\text { Veronica } \\
\text { polita }\end{array}$ & + & + & - & + & + & + & - & - & - & + & III \\
\hline $\mathrm{T}$ & FE & $\begin{array}{l}\text { Mercurialis } \\
\text { annua }\end{array}$ & + & 1 & + & - & + & - & + & + & 1 & 2 & $\mathrm{~V}$ \\
\hline $\mathrm{T}$ & FE & $\begin{array}{l}\text { Thlaspi } \\
\text { arvense }\end{array}$ & - & - & - & - & - & + & - & - & - & + & I \\
\hline $\mathrm{T}$ & $\mathrm{PCH}$ & $\begin{array}{l}\text { Chenopodium } \\
\text { polyspermum }\end{array}$ & 1 & + & + & + & 2 & 3 & 1 & 2 & + & 2 & $\mathrm{~V}$ \\
\hline $\mathrm{T}-\mathrm{H}$ & $\mathrm{PCH}$ & $\begin{array}{l}\text { Lamium } \\
\text { purpureum }\end{array}$ & - & - & - & + & + & + & - & + & - & - & II \\
\hline $\mathrm{T}$ & $\mathrm{PCH}$ & $\begin{array}{l}\text { Lamium } \\
\text { amplexicaule }\end{array}$ & - & - & - & + & + & - & - & - & + & - & II \\
\hline $\mathrm{T}$ & $\mathrm{PCH}$ & $\begin{array}{l}\text { Polygonum } \\
\text { persicaria }\end{array}$ & - & - & - & - & + & - & - & + & + & + & II \\
\hline $\mathrm{T}$ & $\mathrm{PCH}$ & $\begin{array}{l}\text { Euphorbia } \\
\text { helioscopia }\end{array}$ & - & - & - & - & + & - & - & - & - & - & I \\
\hline $\mathrm{T}$ & $\mathrm{CH}$ & $\begin{array}{l}\text { Datura } \\
\text { stramonium }\end{array}$ & 3 & 3 & 2 & 3 & + & - & + & 1 & 2 & 2 & V \\
\hline $\mathrm{T}$ & $\mathrm{CH}$ & $\begin{array}{l}\text { Chenopodium } \\
\text { album }\end{array}$ & - & - & + & + & + & 1 & 1 & - & + & + & IV \\
\hline $\mathrm{T}$ & $\mathrm{CH}$ & $\begin{array}{l}\text { Chenopodium } \\
\text { hybridum }\end{array}$ & - & - & - & + & + & 1 & 3 & 2 & + & - & III \\
\hline $\mathrm{T}$ & $\mathrm{CH}$ & $\begin{array}{l}\text { Chaenorhinum } \\
\text { minus }\end{array}$ & - & - & - & - & - & - & + & - & - & - & I \\
\hline $\mathrm{T}$ & $\mathrm{CH}$ & $\begin{array}{l}\text { Atriplex } \\
\text { patula }\end{array}$ & - & - & - & - & - & - & + & - & + & - & I \\
\hline $\mathrm{T}$ & $\mathrm{CH}$ & $\begin{array}{l}\text { Solanum } \\
\text { nigrum }\end{array}$ & + & 1 & + & 2 & 1 & 2 & - & + & + & + & $\mathrm{V}$ \\
\hline $\mathrm{T}$ & $\mathrm{CH}$ & $\begin{array}{l}\text { Amaranthus } \\
\text { retroflexus }\end{array}$ & - & - & + & - & + & + & + & + & - & - & III \\
\hline G & $\mathrm{CH}$ & $\begin{array}{l}\text { Sonchus } \\
\text { arvensis }\end{array}$ & - & + & + & + & - & - & - & - & - & - & II \\
\hline $\mathrm{T}$ & $\mathrm{CH}$ & $\begin{array}{l}\text { Capsella } \\
\text { bursa pastoris }\end{array}$ & + & - & + & + & - & + & - & - & - & + & III \\
\hline $\mathrm{T}$ & SI & $\begin{array}{l}\text { Sisymbrium } \\
\text { officinale }\end{array}$ & + & - & - & - & - & - & - & - & - & - & I \\
\hline $\mathrm{T}$ & SI & $\begin{array}{l}\text { Brassica } \\
\text { napus }\end{array}$ & - & - & + & - & - & - & - & - & - & - & I \\
\hline
\end{tabular}


Table 1 (continued): Mercurialetum annuae Krusem. and Vlieg. 39 em. Th. Müller facies with Datura stramonium and Hyoscyamus niger.

\begin{tabular}{|c|c|c|c|c|c|c|c|c|c|c|c|c|c|}
\hline \multicolumn{3}{|c|}{ Number of sample } & 1 & 2 & 3 & 4 & 5 & 6 & 7 & 8 & 9 & 10 & \\
\hline \multicolumn{3}{|c|}{ Size of sample } & 25 & 20 & 25 & 35 & 12 & 20 & 113 & 30 & 30 & 12 & \\
\hline \multicolumn{3}{|c|}{ Coverage degree (\%) } & 65 & 50 & 30 & 40 & 45 & 75 & 60 & 60 & 30 & 55 & \\
\hline Biof. & PhSoc & & & & & & & & & & & & $\mathrm{C}$ \\
\hline $\mathrm{T}$ & CAU & $\begin{array}{l}\text { Euphorbia } \\
\text { exigua }\end{array}$ & - & - & - & - & - & - & + & - & - & - & I \\
\hline G-H & CAU & $\begin{array}{l}\text { Lathyrus } \\
\text { tuberosus }\end{array}$ & - & + & + & + & + & + & + & + & + & + & $\mathrm{V}$ \\
\hline $\mathrm{T}$ & SE & $\begin{array}{l}\text { Viola } \\
\text { arvensis }\end{array}$ & - & - & + & + & - & - & + & - & - & - & II \\
\hline $\mathrm{T}$ & SE & $\begin{array}{l}\text { Anagallis } \\
\text { arvensis }\end{array}$ & + & - & - & - & + & - & - & - & - & - & I \\
\hline $\mathrm{T}$ & SE & $\begin{array}{l}\text { Papaver } \\
\text { rhoeas }\end{array}$ & - & - & - & + & - & - & - & - & - & - & I \\
\hline G & SE & $\begin{array}{l}\text { Convolvulus } \\
\text { arvensis }\end{array}$ & + & + & - & - & + & + & - & - & - & + & III \\
\hline $\mathrm{T}-\mathrm{H}$ & ON & $\begin{array}{l}\text { Hyoscyamus } \\
\text { niger }\end{array}$ & - & - & - & + & 1 & 1 & 1 & 2 & - & - & III \\
\hline $\mathrm{H}$ & ON & $\begin{array}{l}\text { Carduus } \\
\text { acanthoides }\end{array}$ & - & - & - & + & - & - & + & - & - & - & $\mathrm{I}$ \\
\hline $\mathrm{H}$ & ART & $\begin{array}{l}\text { Cirsium } \\
\text { vulgare }\end{array}$ & - & - & - & - & - & - & + & - & - & - & I \\
\hline $\mathrm{H}$ & ART & $\begin{array}{l}\text { Dipsacus } \\
\text { laciniatus }\end{array}$ & - & - & - & - & - & - & + & - & - & - & I \\
\hline $\mathrm{H}$ & ART & $\begin{array}{l}\text { Daucus } \\
\text { carota }\end{array}$ & - & + & - & - & - & - & - & - & - & - & I \\
\hline G & ART & $\begin{array}{l}\text { Cirsium } \\
\text { arvense }\end{array}$ & + & + & + & - & - & 2 & - & - & - & 1 & III \\
\hline $\mathrm{T}$ & ART & $\begin{array}{l}\text { Galium } \\
\text { aparine }\end{array}$ & - & - & - & - & - & - & + & - & - & - & I \\
\hline $\mathrm{H}$ & AR & $\begin{array}{l}\text { Arrhenatherum } \\
\text { elatius }\end{array}$ & - & - & - & + & + & + & - & - & - & - & II \\
\hline $\mathrm{C}-\mathrm{H}$ & $\mathrm{AR}$ & $\begin{array}{l}\text { Trifolium } \\
\text { repens }\end{array}$ & - & - & - & - & - & + & - & - & - & + & I \\
\hline $\mathrm{H}$ & AR & $\begin{array}{l}\text { Lolium } \\
\text { perenne }\end{array}$ & - & - & - & - & - & - & - & - & + & + & I \\
\hline $\mathrm{H}$ & AR & $\begin{array}{l}\text { Chrysanth. } \\
\text { leucanthemum }\end{array}$ & - & - & - & - & - & - & - & - & + & - & I \\
\hline $\mathrm{H}$ & MA & $\begin{array}{l}\text { Trifolium } \\
\text { pratense }\end{array}$ & - & - & + & - & - & - & - & - & - & - & I \\
\hline $\mathrm{H}$ & MA & $\begin{array}{l}\text { Dactylis } \\
\text { glomerata }\end{array}$ & - & - & - & 1 & 2 & - & + & - & - & - & II \\
\hline
\end{tabular}


Table 1 (continued): Mercurialetum annuae Krusem. and Vlieg. 39 em. Th. Müller facies with Datura stramonium and Hyoscyamus niger.

\begin{tabular}{|c|c|c|c|c|c|c|c|c|c|c|c|c|c|}
\hline \multicolumn{3}{|c|}{ Number of sample } & 1 & 2 & 3 & 4 & 5 & 6 & 7 & 8 & 9 & 10 & \\
\hline \multicolumn{3}{|c|}{ Size of sample } & 25 & 20 & 25 & 35 & 12 & 20 & 113 & 30 & 30 & 12 & \\
\hline \multicolumn{3}{|c|}{ Coverage degree (\%) } & 65 & 50 & 30 & 40 & 45 & 75 & 60 & 60 & 30 & 55 & \\
\hline Biof. & PhSoc & & & & & & & & & & & & C \\
\hline $\mathrm{H}$ & MA & $\begin{array}{l}\text { Taraxacum } \\
\text { officinale }\end{array}$ & 1 & 1 & 1 & + & 2 & 1 & + & + & 2 & + & $\mathrm{V}$ \\
\hline G & AgR & $\begin{array}{l}\text { Elymus } \\
\text { repens }\end{array}$ & 2 & 1 & 1 & + & - & - & + & - & - & - & III \\
\hline G-H & AgR & $\begin{array}{l}\text { Rorippa } \\
\text { sylvestris }\end{array}$ & - & - & - & + & - & - & - & - & - & - & I \\
\hline $\mathrm{H}$ & AgR & $\begin{array}{l}\text { Festuca } \\
\text { arundinacea }\end{array}$ & - & - & - & - & - & - & + & - & - & - & I \\
\hline $\mathrm{H}$ & AG & $\begin{array}{l}\text { Potentilla } \\
\text { reptans }\end{array}$ & - & - & - & - & - & - & 2 & + & - & - & I \\
\hline $\mathrm{T}$ & PL & $\begin{array}{l}\text { Polygonum } \\
\text { aviculare }\end{array}$ & + & - & + & + & + & - & + & + & + & + & IV \\
\hline $\mathrm{H}$ & PL & $\begin{array}{l}\text { Plantago } \\
\text { major }\end{array}$ & - & - & - & + & + & + & - & - & - & - & II \\
\hline $\mathrm{T}-\mathrm{H}$ & $\mathrm{ME}$ & $\begin{array}{l}\text { Medicago } \\
\text { lupulina }\end{array}$ & - & - & - & + & - & + & - & - & - & - & I \\
\hline $\mathrm{H}$ & $\mathrm{ME}$ & $\begin{array}{l}\text { Euphorbia } \\
\text { esula }\end{array}$ & - & - & - & - & - & - & - & + & - & - & I \\
\hline $\mathrm{H}$ & TR & $\begin{array}{l}\text { Agrimonia } \\
\text { eupatoria }\end{array}$ & - & - & - & - & + & + & - & + & - & - & II \\
\hline $\mathrm{H}$ & $\mathrm{PH}$ & $\begin{array}{l}\text { Poa } \\
\text { palustris }\end{array}$ & - & - & - & - & - & + & - & - & - & - & I \\
\hline$P$ & $\mathrm{AU}$ & $\begin{array}{l}\text { Pyrus } \\
\text { pyraster }\end{array}$ & - & - & - & - & - & - & - & + & - & - & I \\
\hline $\mathrm{C}$ & $\mathrm{CO}$ & $\begin{array}{l}\text { Rubus } \\
\text { caesius }\end{array}$ & - & - & - & - & - & - & - & + & - & - & I \\
\hline
\end{tabular}

Abbreviations of the phyto-coenological units used in the table: $\mathrm{FE}=$ Alliance FumarioEuphorbion; $\mathrm{PCH}=$ Ordre Polygono-Chenopodietalia; $\mathrm{CH}=$ Classe Chenpodietea; $\mathrm{SI}=$ Alliance Sysimbrion officinals; $\mathrm{CAU}=$ Alliance Caucalidion lappulae; $\mathrm{SE}=$ Ordre Seacalietalia and Classe Secalietea; $\mathrm{ON}=$ Ordre Onopordetalia; $\mathrm{ART}=$ Classe Artemisietea; $\mathrm{AR}=$ Ordre Arrhenatheretalia; $\mathrm{MA}=$ Classe Molinio-Arrhenatheretea; AgR = Alliance Agropyro-Rumicion; AG = Classe Agrostietea stoloniferae; PL = Classe Plantaginetea; $\mathrm{ME}=$ Alliance Mesobromion erecti; $\mathrm{TR}=$ Alliance Trifolion medii; $\mathrm{PH}=$ Classe Phragmitetea; $\mathrm{AU}=$ Alliance Alno-Ulmion; $\mathrm{CO}=$ Ordre Convolvuletalia.

Date of sampling: sample 01-09.09.1992, sample 10-16.09.1992. 
In years with longtime floods, in the deeper flood channels, i.e. depressions of the newly developing meadows, occur sometimes short-lived annual species adapted to wetness. They colonise the meadow type of Poa palustris, building open pioneer communities. These communities are dominated by Potentilla supina accompanied by other short-lived species such Gnaphalium luteo-album, Chenopodium spp. and Polygonum spp., all being reactivated from the diaspore bank of the soil. Some species have a high longevity in the soil, i.e. Fumaria officinalis, being mentioned more than 500 years (Oberdorfer, 2001). Mercurialis annua, Potentilla supina and Chenopodium botryoides, as well as Chenopodium polyspermum, occur only from time to time, as a function of the ecological condition of the year.

Table 2: Potentilla supina - community of short living species.

\begin{tabular}{|c|c|c|c|c|c|c|c|}
\hline & Number of sample & 1 & 2 & 3 & 4 & 5 & 6 \\
\hline & Coverage degree (\%) & 20 & 70 & 60 & 60 & 55 & 45 \\
\hline \multicolumn{8}{|l|}{ Biof. } \\
\hline $\mathrm{T}(\mathrm{H})$ & Potentilla supina & 1 & 3 & 1 & 3 & 2 & 1 \\
\hline $\mathrm{T}$ & Capsella bursa pastoris & 1 & + & + & + & + & + \\
\hline $\mathrm{T}$ & Polygonum persicaria & - & + & - & + & - & - \\
\hline $\mathrm{T}$ & Chenopodium album & + & - & + & - & - & - \\
\hline $\mathrm{T}$ & Chenopodium polyspermum & 1 & - & - & - & - & - \\
\hline $\mathrm{T}$ & Chenopodium viride & - & - & - & + & + & - \\
\hline $\mathrm{T}$ & Chenopodium botryoides & - & 2 & - & - & - & - \\
\hline $\mathrm{T}$ & Gnaphalium luteoalbum & - & 2 & - & - & - & - \\
\hline $\mathrm{T}$ & Polygonum lapathifolium & - & + & - & - & - & - \\
\hline $\mathrm{T}$ & Anagallis arvensis & - & - & 1 & + & + & + \\
\hline $\mathrm{T}$ & Lamium amplexicaule & - & - & + & + & + & + \\
\hline $\mathrm{T}$ & Thlaspi arvense & - & - & - & + & - & - \\
\hline $\mathrm{T}$ & Polygonum aviculare & - & - & + & - & - & - \\
\hline $\mathrm{T}$ & Atriplex hastata & - & - & - & + & + & - \\
\hline $\mathrm{T}$ & Fumaria officinalis & - & - & - & - & - & + \\
\hline $\mathrm{T}$ & Euphorbia helioscopia & - & - & - & - & - & + \\
\hline $\mathrm{H}$ & Taraxacum officinale & - & + & 3 & 3 & 2 & 3 \\
\hline $\mathrm{H}$ & Plantago major & - & - & + & + & + & + \\
\hline $\mathrm{H}$ & Plantago intermedia & - & + & - & - & - & - \\
\hline $\mathrm{H}$ & Trifolium repens & - & - & 1 & + & - & - \\
\hline $\mathrm{H}(\mathrm{T})$ & Medicago lupulina & - & + & - & + & + & - \\
\hline $\mathrm{H}$ & Rumex crispus & - & - & + & & + & - \\
\hline $\mathrm{H}$ & Erigeron annuus & - & - & + & - & + & - \\
\hline $\mathrm{H}$ & Poa palustris & - & - & + & - & - & - \\
\hline $\mathrm{H}$ & Cirsium vulgare & - & - & + & + & - & - \\
\hline $\mathrm{H}$ & Vicia cracca & - & - & + & - & + & - \\
\hline $\mathrm{H}$ & Alopecurus pratensis & - & - & - & + & - & - \\
\hline $\mathrm{H}$ & Rumex obtusifolius & - & - & - & - & + & - \\
\hline G-H & Rorippa sylvestris & - & + & + & + & 2 & + \\
\hline $\mathrm{G}$ & Agropyron repens & + & - & - & - & - & - \\
\hline G & Cirsium arvense & - & - & - & - & + & - \\
\hline
\end{tabular}

Sampling data and place: $1=13.06 .1994$ plot "Schafweide", Polder B; $2=05.08 .1999$, in the flood channel of "Plattenacker", Polder C; 3-6 = 08.06.2000 "Plattenacker" flood channel. 


\section{CONCLUSIONS}

It is quite obvious that in floodplains the succession process is different from the succession in wet fallow lands outside the floodplain. This difference is caused by the coincidence of the flooding factor with other ecological conditions.

The succession progresses very rapidly and follows different stages from the initial pioneer therophytes to different structured stages of herbs and grasses. At the same time the studies show that a considerable genetic potential with numerous rare and endangered species can be activated by significant and unknown residues and by the seed bank in the soil. This last plays an important role in the evolution of the area.

It became clear in the course of the monitoring, that there are many species recolonising the area only through the mechanism of diaspores of the soil.

The reactivation of the seed bank in the soil is in strong relation to the flooding regime of each of the studied years and the occurrences of wet and dry periods. Longer wet and dry periods create different conditions in the vegetation cover influencing the vitality of species in function of their flood tolerance or capacity to survive dry summers. The gaps arising in the turf favour the colonization by short-lived species from the seed bank of the soil.

Rooting up by wild boar creates as well open larger or smaller patches in the developing meadows, leading to the development of micro-succession, with many species present from the seed bank of the soil.

Diaspore banks influence the dynamics of these plant communities and should be considered in the programmes of sustainable development and conservation of floodplain meadows. 


\section{ACKNOWLEDGEMENTS}

During the long time of research and monitoring in the frame of the succession project, we benefited from the technical support and help of the Forestry Office Forstamt Groß-Gerau /Kühkopf Knoblosaue. In particular I would like to express my gratitude to Mr. Baumgärtel R. for its valuable help, fruitful discussions and assistance during field activities in the study area of the Nature Reserve Kühkopf-Knoblohsaue. 


\section{REFERENCES}

1. Bornkamm R., Eggert A., Küppers M., Schmid B. and Stöcklin J. (eds), 1991 - Liste populatiosbiologisch relevanter Begriffe, in Schmid B and Stöcklin J. - Populationsbiologie der Pflanzen, Birkhäuser Verlag Basel-Boston - Berlin, 9-13. (in German)

2. Braun-Blanquet J., 1964 - Pflanzensoziologie, Grunzüge der Vegetationskunde, Auflage, Springer Verlag Berlin, Wien, New York, 3, 865. (in German)

3. Curtean-Bănăduc A., Schneider-Binder E. and Bănăduc D., 2014 - The importance of the riverine ligneous vegetation for the Danube Basin lotic ecosystems, in Cianfaglione K. (ed.) L’importanza degli Alberi e del Bosco, Cultura, scienza e coscienza del territorio, Temi Edit., Trento, Italia, ISBN: 978-88-973772-63-9, I-II, 187-210.

4. Dister E., Schneider E., Schneider E., Fritz H.-G., Flößer E. and Winkel S., 1986 - Erfassung der tierischen und pflanzlichen Sukzession auf den aufgelassenen Ackerflächen des Kühkopfs im NSG Kühkopf-Knoblochsaue, im Auftrag des Landes Hessen vertreten durch den Hessischen Minister für Umwelt und Energie in Wiesbaden, 113. (in German)

5. Dister E., Schneider E., Schneider E., Fritz H.-G., Winkel S. and Flößer E., 1987 - Erfassung der tierischen und pflanzlichen Sukzession auf den aufgelassenen Ackerflächen des Kühkopfs im NSG "Kühkopf-Knoblochsaue”. Forschungsergebnisse 1987, Bericht, WWF-Auen-Institut Rastatt, erarbeitet im Auftrag der BFN, Darmstadt, 168. (in German)

6. Dister E., Schneider E., Fritz H.-G., Flößer E., Schneider E. and Winkel S., 1991 - Erfassung der Sukzession auf den aufgelassenen Ackerflächen des Kühkopfs im NSG "KühkopfKnoblochsuae", Ergebnisse 1991, WWF-Auen-Institut, Rastatt, im Auftrag der BFN, Darmstadt, 203. (in German)

7. Dister E., Schneider E., Schneider E., Fritz H.-G., Winkel S. and Flößer E., 1992 Großflächige Renaturierung des "Kühkopfes" in der hessischen Rheinaue - Ablauf, Ergebnisse und Folgerungen der Sukzessionsforschung, in Auen - gefährdete Lebensadern Europas. Renaturierung von Flussauen, Tagungsdokumentation des internationalen Kongresses in Rastatt; Beiträge der Akademie für Natur- und Umweltschutz Baden-Württemberg, 13 b, 20-36. (in German)

8. $\quad$ Ellenberg H., Weber H. E., Düll R., Wirth V. and Werner W., 2001 - Zeigerwerte von Pflanzen in Mitteleuropa, Scripta Geobotanica, 18, 1-264, Göttingen. (in German)

9. Fischer A., 1987 - Untersuchungen zur Populationsdynamik am Beginn von Sekundärsukzessionen, Dissertationes Botanicae, 110, 234, Berlin-Stuttgart. (in German)

10. Müller-Schneider P., 1977 - Verbreitungsbiologie (Diasporologie) der BlütenpflanzenVeröffentlichungen des Geobotanischen Institutes der ETH, Stiftung Rübel, Zürich, volume 61, 226. (in German)

11. Oberdorfer E., 1993 - Süddeutsche Pflanzengesellschaften, III, 455, Fischer Verlag Jena. (in German)

12. Oberdorfer E., 2001 - Pflanzensoziologische Exkursionsflora für Deutschland und angrenzende Gebiete, 8 Auflage, Verlag Eugen Ulmer Stuttgart, 1051. (in German)

13. Poschlod P., 1991 - Diasporenbanken in Böden - Grundlagen und Bedeutung, in Populationsbiologie der Pflanzen, hrsg. von Schmid B. and Stöcklin J., 15-35, Birkhäuser, Basel-Boston Berlin. (in German)

14. Schmidt W., 1981 - Ungestörte und gelenkte Sukzession auf Brachäckern, Scripta Geobotanica, 15, 1-199, Göttingen. (in German)

15. Schneider E., 1995 - Zur Vegetationsentwicklung auf den aufgelassenen Ackerflächen des Kühkopfs und das damit verbundene Auftreten seltener Arten. Zeitschrift für Vogel, und Naturschutz in Südhessen, Collurio 13, 67-78, Arbeitskreis Darmstadt der Hessischen Gesellschaft für Ornithologie und Naturschutz e. V. (HGON). (in German) 
16. Schneider E., 2001 - Restoration of floodplain meadows and forests, Results of 15 years of monitoring in natural and controlled succession on re-flooded areas in the Nature Reserve Kühkopf-Knoblochsaue/Upper Rhine, River restoration in Europe, Practical approaches, Conference on river restoration Wageningen, The Netherlands 2000, Proceedings edited by Nijland H. J. and Cals M. J. R., RIZA rapport no. 2001.023, 197-199.

17. Schneider E., 2002 - Vom Acker zur Auenwiese, 20 Jahre Grünlandsukzession auf dem Kühkopf, in 50 Jahre Naturschutzgebiet Kühkopf-Knoblochsaue, Regierungspräsidium Darmstadt, 43-49. (in German)

18. Schneider E. and Dister E., 1993 - Erfassung der Sukzession auf den aufgelassenen Ackerflächen des Kühkopfs im NSG "Kühkopf-Knoblochsaue”, Ergebnisse 1993, WWF-AuenInstitut, Rastatt, im Auftrag des Hessischen Ministeriums für Landesentwicklung, Wohnen, Landwirtschaft, Forsten und Naturschutz, 8, Project report. (in German)

19. Schneider E., Dister E. and Schneider E., 1994 - Erfassung der Sukzession auf den aufgelassenen Ackerflächen des Kühkopfs im NSG "Kühkopf-Knoblochsaue" Ergebnisse, WWF-Auen-Institut, Rastatt, im Auftrag des Hessischen Ministeriums für Landesentwicklung, Wohnen, Landwirtschaft, Forsten und Naturschutz, 101, Project Report. (in German) 